\title{
Population trends and fluctuations in Swedish woodpeckers
}

\author{
SVEN G. NILSSON, OLA OLSSON, SÖREN SVENSSON \& ULF WIKTANDER
}

\begin{abstract}
This is a quantitative study of population changes in four nonmigratory woodpeckers in Sweden. Data were collected during five periods from late autumn to spring and during the breeding season, mainly using point counts. Most analyses are based on the proportion of the routes (each with 20 points) with observation of the species in each year. From 1975 to 1991 there were no population trends in the Great Spotted and Black Woodpeckers, but decreases in the Green and Lesser Spotted Woodpeckers. The mean annual decrease was about $2 \%$ in the Green and $4 \%$ in the Lesser Spotted Woodpecker. There was no trend in winter weather over this period, and only for the Black Woodpecker we found associations between mild winters

and numbers recorded. The Great Spotted Woodpecker population increased in years with a high spruce seed supply. In southernmost Sweden frequency of observation was higher for the Green and, in winter, for the Black Woodpecker than further north, while the reverse was true for the Great Spotted Woodpecker. No regional difference was found for the Lesser Spotted Woodpecker.

Sven G.Nilsson, Ola Olsson, Sören Svensson \& UlfWikıander, Department of Ecology, Lund University, Ecology Building, S-223 62 Lund, Sweden.
\end{abstract}

\section{Introduction}

Woodpeckers are most common in old, unmanaged forests where, in Europe, up to eight species can occur in the same forest (e.g. Tomiałojć et al. 1984). Thus, woodpeckers are often considered to be indicators of management impact (e.g. Scherzinger 1990, Spitznagel 1990).

In many managed forests in Sweden, only the Black Woodpecker Dryocopus martius and the Great Spotted Woodpecker Dendrocopos major occur (e.g. Nilsson 1979). The Middle Spotted Woodpecker Dendrocopos medius, dependent on old, open oak-dominated forests in Sweden, decreased over the last hundred years and finally disappeared in 1982 (Pettersson 1985). The White-backed Woodpecker Dendrocopos leucotos requires extensive forests with many old deciduous trees and snags (Aulén 1985). It has also contracted considerably from its former breeding range (Aulén 1986). In 1988, its population was estimated at $80-110$ pairs (Aulén et al. 1989).

In a recent survey of population trends among 40 common bird species and their response to modern forestry (Svensson in press) four woodpecker species were included. Population indices for Black and Great Spotted Woodpecker showed no change, while the Green Woodpecker Picus viridis and the Wryneck Jynx torquilla decreased. It was suggested that the decline of the Green Woodpecker was an effect of the decrease of deciduous trees.

For the other three Swedish woodpecker species, however, there are no published data on long term population changes, except for some local reports. Ornithologists have suggested that the Lesser Spotted Woodpecker Dendrocopos minor and the Three-toed Woodpecker Picoidestridactylus have decreased, while the Grey-headed Woodpecker Picus canus may have increased somewhat along the southern border of its range (SOF 1990).

Here we report on the population trends and fluctuations in the Green, Black, Great Spotted and Lesser Spotted Woodpeckers in different seasons and regions in Sweden. 


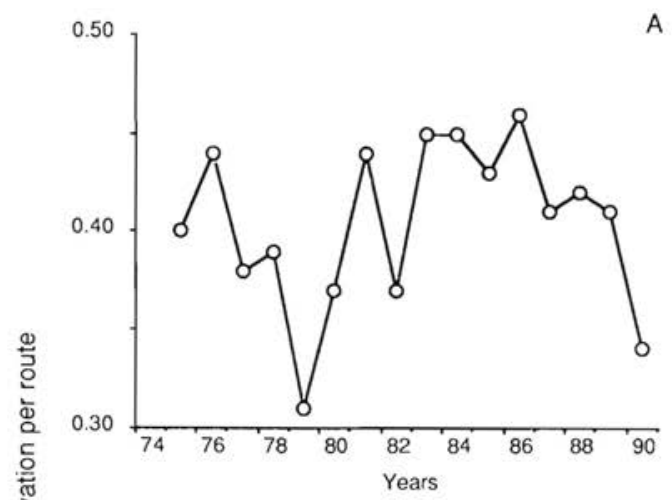

B

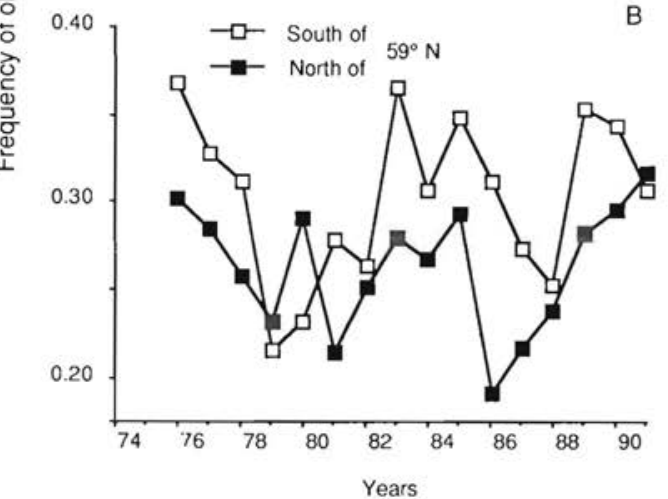

Fig. 1. The frequency of observation (proportion of point count routes with observations) of the Black Woodpecker in (A) May - June and (B) October - March. The material for the winter period is separated in two groups, north and south of $59^{\circ} \mathrm{N}$.

Andelen punkttaxeringar med observation av spillkråka un$\operatorname{der}(A)$ maj - juni och (B) oktober - mars. Materialet frän vinterperioden är uppdelat i två grupper (söder resp. norr om Strömstad-Hallsberg-Katrineholm).

\section{Methods}

The census data were extracted from the Swedish Winter Bird Count (1975/76 to 1990/91) and the Swedish Breeding Bird Census (1975-1990). The main method is a point count technique where volunteer participants establish routes with 20 points. At each point all individual birds, heard or seen, are counted during five minutes. In winter, counts are made in five periods from October through early March. In the breeding season one count is made in May-June. For a detailed description of field methods see e.g. Källander et al. (1977) and Svensson (1991). Between 646 and

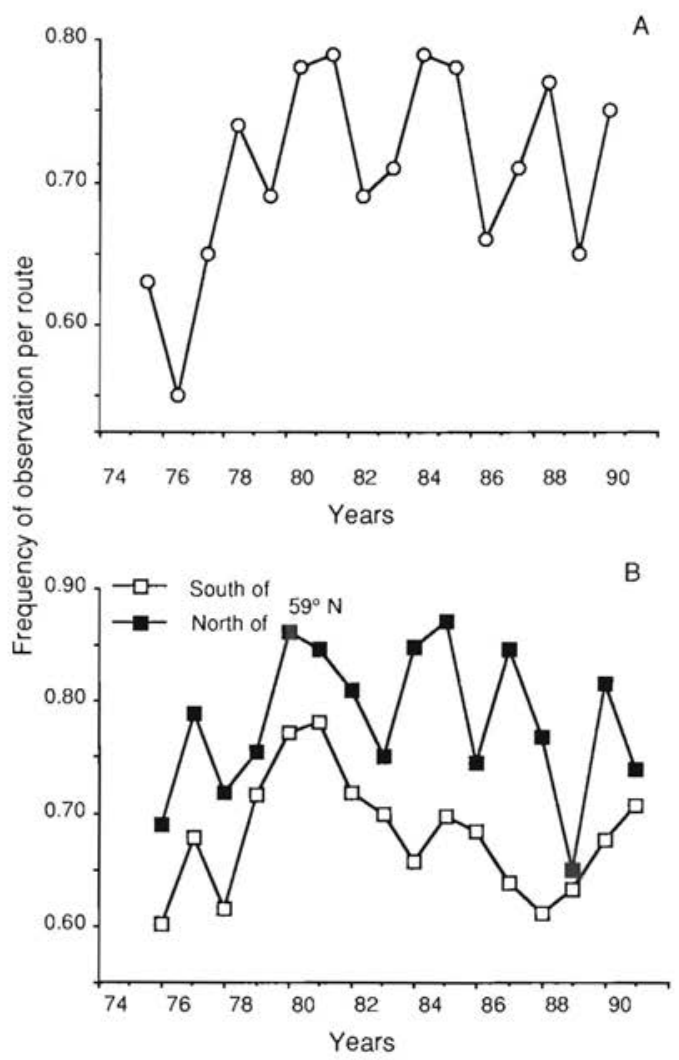

Fig. 2. Same as in Fig. 1 for Great Spotted Woodpecker. Samma som i Fig. I för större hackspett.

1579 routes were censused each year in the Winter Bird Count and between 83 and 208 in the Breeding Bird Census. In order to increase the sample size for the Lesser Spotted Woodpecker we also included data from territory mapping plots in the breeding season, using all plots with at least one occupied territory in 1975-90 (10-18 plots per year).

We used two kinds of population data. The first was simply the proportion of routes with observation of the species in each year (termed frequency of observation), separating winter and breeding season. The second was based on the change of the number of individuals on routes that were common between two adjacent years. 


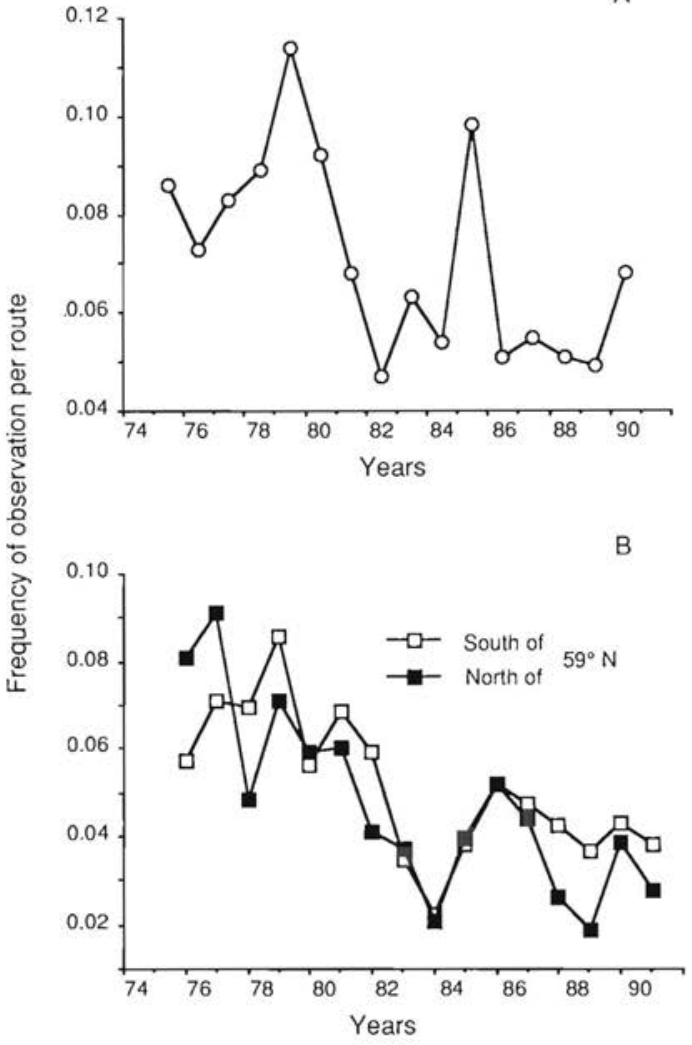

Fig. 3. Same as in Fig. 1 for Lesser Spotted Woodpecker. Samma som i Fig. I för mindre hackspett

These estimates of change were concatenated to form a series of annual indices with the mean index for 1975 to 1984 equal to 100 (see Svensson 1991 for methods of calculation).

We used the frequency of observation in most of the analyses, arcsinus transforming it for normalization before using it in analysis of variance. The advantage of using the frequency of observation is that double counts of individual birds from adjacent points are excluded and values from different years are independent from each other. The disadvantage is that it is less sensitive to changes in numbers than is an index based on totals of individual birds. Hence, in the analyses of effects of winter temperatures and winter food we have used the population indices instead.

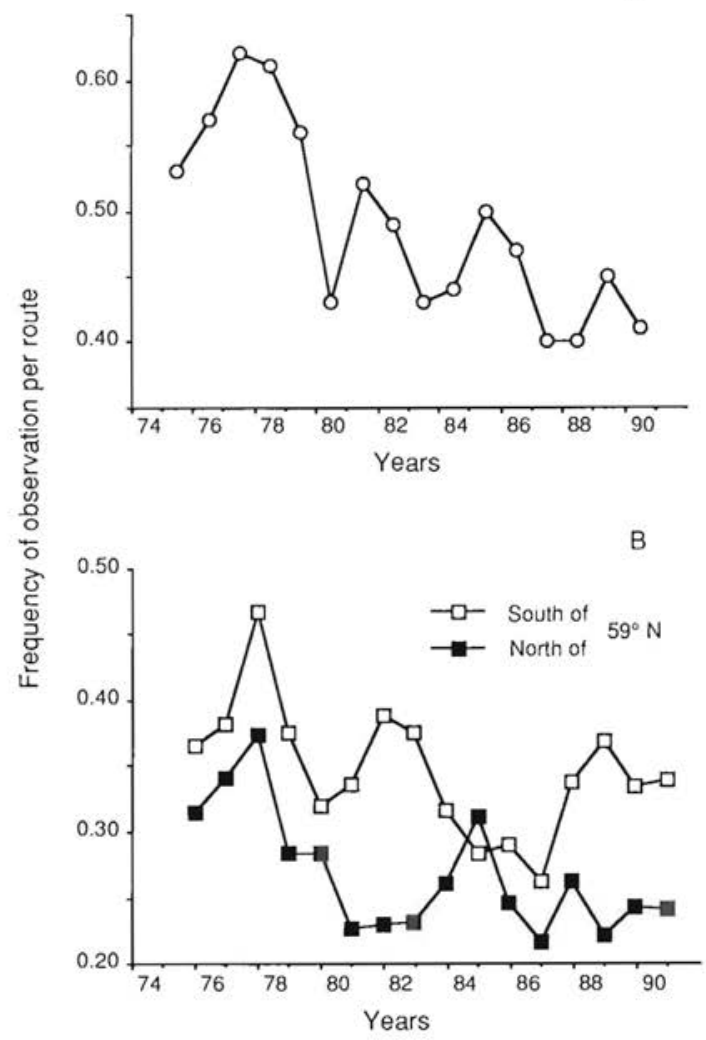

Fig. 4. Same as in Fig. 1 for Green Woodpecker.

Samma som i Fig. 1 för gröngöling.

We divided the material into two geographical groups with about an equal number of routes in each. The division was at approximately $59^{\circ} \mathrm{N}$, leaving one fourth of the country in a southern region and the rest in a northern. Most of the routes in the latter region were however located in south central Sweden ( south of about $62^{\circ} \mathrm{N}$ ) and very few in the northern half (see map in Svensson 1991). The geographical distribution of routes has been stable over the years (Svensson unpubl.).

Mean winter temperature was calculated from the mean monthly temperatures in December-February for two cities in south and central Sweden (Växjö and Örebro). Mean temperature is closely correlated with mean minimum and mean maximum temperature and also with mean snow thickness (Nilsson 1987). 
Table 1. Frequency of observation of four woodpecker species on point count routes, and the slopes of the population trends in 1975/76 - 1990/91 (winter) and 1975 - 1990 (breeding season)

Andel av punkttaxeringsrutterna med någon observation av fyra hackspettsarter samt förändringstakten i observations. frekvens 1975/76 - 1990/91 (vinter) och 1975 - 1990 (häckningstid).

\begin{tabular}{|c|c|c|c|c|}
\hline & \multicolumn{2}{|c|}{$\begin{array}{l}\text { Frequency } \\
\text { Andel }\end{array}$} & \multicolumn{2}{|c|}{$\begin{array}{l}\text { Slope } \\
\text { Förändringstakt }\end{array}$} \\
\hline & $\begin{array}{l}\text { winter } \\
\text { vinter }\end{array}$ & $\begin{array}{l}\text { breeding } \\
\text { season } \\
\text { häck- } \\
\text { ningstid }\end{array}$ & $\begin{array}{l}\text { winter } \\
\text { vinter }\end{array}$ & $\begin{array}{l}\text { breeding } \\
\text { season } \\
\text { häck- } \\
\text { ningstid }\end{array}$ \\
\hline \multicolumn{5}{|c|}{$\begin{array}{l}\text { Green Woodpecker } \\
\text { Gröngöling }\end{array}$} \\
\hline $\begin{array}{l}\text { South of } 59^{\circ} \mathrm{N} \\
\text { North of } 59^{\circ} \mathrm{N} \\
\text { All routes }\end{array}$ & $\begin{array}{l}0.346 \\
0.268 \\
0.310\end{array}$ & $\begin{array}{l}0.518 \\
0.443 \\
0.482\end{array}$ & $\begin{array}{l}-0.0051 \\
-0.0064 \\
-0.0059\end{array}$ & $\begin{array}{l}-0.0091 \\
-0.0172 \\
-0.0121\end{array}$ \\
\hline \multicolumn{5}{|c|}{$\begin{array}{l}\text { Black Woodpecker } \\
\text { Spillkråka }\end{array}$} \\
\hline $\begin{array}{l}\text { South of } 59^{\circ} \mathrm{N} \\
\text { North of } 59^{\circ} \mathrm{N} \\
\text { All routes }\end{array}$ & $\begin{array}{l}0.303 \\
0.263 \\
0.284\end{array}$ & $\begin{array}{l}0.392 \\
0.410 \\
0.401\end{array}$ & $\begin{array}{l}0.0011 \\
0.0003 \\
0.0006\end{array}$ & $\begin{array}{r}0.0028 \\
-0.0009 \\
0.0012\end{array}$ \\
\hline \multicolumn{5}{|c|}{$\begin{array}{l}\text { Great Spotted Woodpecker } \\
\text { Större hackspett }\end{array}$} \\
\hline $\begin{array}{l}\text { South of } 59^{\circ} \mathrm{N} \\
\text { North of } 59^{\circ} \mathrm{N} \\
\text { All routes }\end{array}$ & $\begin{array}{l}0.680 \\
0.782 \\
0.727\end{array}$ & $\begin{array}{l}0.692 \\
0.731 \\
0.711\end{array}$ & $\begin{array}{r}-0.0011 \\
0.0002 \\
-0.0003\end{array}$ & $\begin{array}{l}0.0036 \\
0.0085 \\
0.0058\end{array}$ \\
\hline \multicolumn{5}{|c|}{$\begin{array}{l}\text { Lesser Spotted Woodpecker } \\
\text { Mindre hackspett }\end{array}$} \\
\hline South of $59^{\circ} \mathrm{N}$ & 0.051 & 0.057 & -0.0024 & -0.0020 \\
\hline North of $59^{\circ} \mathrm{N}$ & 0.047 & 0.047 & -0.0035 & -0.0024 \\
\hline All routes & 0.049 & 0.052 & -0.0029 & -0.0025 \\
\hline
\end{tabular}

\section{Results}

\section{Population trends}

Data from different seasons and regions were consistent in indicating no trend in populations of the Black and the Great Spotted Woodpeckers (Fig. 1 and 2). Analysis of covariance of frequency of observation for these two species indicated no trend over time (Table 1 and 2).

However, the Lesser Spotted Woodpecker decreased significantly $(\mathrm{P}<0.001)$ with the same rate in southern as in central Sweden (Table 2). We have little data from the breeding season for this species, but they are consistent with the result from the winter (Fig. 3). Combining all data the mean annual rate of decrease was $-4.3 \%$ (95\% confidence limits, $-2.3 \%--6.2 \%$ ). For the Green Woodpecker the result was similar, indicating a decrease both in winter and summer (ANCOVA,
Table 2. Analysis of variance of observation frequencies of four woodpecker species over 16 years (continuous variable), winter / breeding season (Period) and south / north of $59^{\circ} \mathrm{N}$ (Region). Only interactions that remained significant $(\mathrm{P}<0.05)$ after backward elimination are reported. The covariate, Year, tests for a trend over time whereas the two categorical variables tests for differences in frequencies between the two periods and regions respectively.

Variansanalys av observationsfrekvenserna (andel av punktrutterna med observation) för fyra hackspettsarter under 16 år (kontinuerlig variabel) period (uppdelat på vinter och häckningssäsong) och region. Att år är en kontinuerlig variabel innebär att trender över tiden testas för sig ("Year"), eller att trenden skiljer sig mellan vinter och häckningstid ("Year*Period") eller regioner ("Year*Region"). För period och region testas skillnaderna mellan de två kategorierna samt eventuella interaktioner. Icke signifikanta interaktioner eliminerades successivt tills endast signifikanta $(P<0.05)$ återstod.

\begin{tabular}{|c|c|c|c|}
\hline & df & F-ratio & $\mathrm{P}$ \\
\hline \multicolumn{4}{|c|}{$\begin{array}{l}\text { Green Woodpecker } \\
\text { Gröngöling }\end{array}$} \\
\hline Year & 1 & 36.7 & $<0.001$ \\
\hline Period & 1 & 11.5 & 0.001 \\
\hline Region & 1 & 25.6 & $<0.001$ \\
\hline Year*Period & 1 & 7.3 & 0.009 \\
\hline \multicolumn{4}{|c|}{$\begin{array}{l}\text { Black Woodpecker } \\
\text { Spillkråka }\end{array}$} \\
\hline Year & 1 & 0.3 & 0.612 \\
\hline Period & 1 & 82.7 & $<0.001$ \\
\hline Region & 1 & 0.6 & 0.438 \\
\hline Period*Region & 1 & 5.0 & 0.029 \\
\hline \multicolumn{4}{|c|}{$\begin{array}{l}\text { Great Spotted Woodpecker } \\
\text { Större hackspett }\end{array}$} \\
\hline Year & 1 & 1.7 & 0.192 \\
\hline Period & 1 & 1.1 & 0.290 \\
\hline Region & 1 & 16.5 & $<0.001$ \\
\hline \multicolumn{4}{|c|}{$\begin{array}{l}\text { Lesser Spotted Woodpecker } \\
\text { Mindre hackspett }\end{array}$} \\
\hline Year & 1 & 14.1 & $<0.001$ \\
\hline Period & 1 & 0.2 & 0.690 \\
\hline Region & 1 & 1.0 & 0.320 \\
\hline
\end{tabular}

$\mathrm{p}<0.001$; Table 2, Fig.4). The annual rate of decrease did differ between seasons (Table 2) but the effect is very weak $\left(r^{2}=0.052\right)$.

We examined frequency of observation for the late autumn (October, November), midwinter (December, January) and late winter (February, March) periods separately. Trends were consistent for different periods except in the Green Woodpecker. For this species the data indicated a decrease in late autumn $(\mathrm{P}<0.001)$, while no significant trends were detected for the two winter periods (slopes $=-0.001$ and -0.004 with $\mathrm{P}=0.84$ and 0.28 , respectively). 
Table 3. Correlation over 16 years between mean winter (December-February) temperatures and population indices in the same winters and subsequent breeding seasons.

Korrelationer mellan medeltemperaturen för december - februari (medelmellan Växjö och Örebro) och populationsindex samt mellan vintertemperaturen och efterföljande vårs häckfågelindex.

\begin{tabular}{lrr}
\hline & $\mathrm{r}$ & \multicolumn{1}{c}{$\mathrm{P}$} \\
\hline Green Woodpecker & & \\
Gröngöling & & \\
Winter index & 0.481 & 0.059 \\
Breeding index & -0.337 & \\
Black Woodpecker & & \\
Spillkråka & & \\
Winter index & 0.567 & 0.022 \\
Breeding index & 0.071 & 0.80 \\
Great Spotted Woodpecker & & \\
Större hackspett & & 0.68 \\
Winter index & -0.114 & 0.66 \\
Breeding index & -0.124 & \\
Lesser Spotted Woodpecker & & 0.38 \\
Mindre hackspett & & 0.78 \\
Winter index & -0.238 & \\
Breeding index & 0.079 & \\
\hline
\end{tabular}

\section{Population fluctuations}

We found no significant associations between indices of woodpecker abundance and mean winter temperatures except in the Black Woodpecker (Table 3). However, for this species the correlation was positive only with the winter index, not with the summer index. Over the years studied mean winter temperatures had no trend $(\mathrm{r}=0.376, \mathrm{~N}=16, \mathrm{P}=0.15)$.

In resident passerines at high latitudes, winter food is also an important determinant of population fluctuations (e.g. van Balen 1980, Nilsson 1987). For the woodpeckers we have data on winter food only for the Great Spotted Woodpecker, which mainly feeds on coniferous seeds when available (Glutz von Blotzheim \& Bauer 1980, Cramp 1985). The analysis indicates a positive effect of spruce seed supply on the size and rate of change of the Great Spotted Woodpecker population (Table 4).

\section{Regional population densities}

The Green and the Black Woodpeckers were more common in southern Sweden than further north, while the reverse was true for the Great Spotted Woodpecker (Table 1 and 2). The same patterns were found in both
Table 4. Spearman rank correlations between spruce seed supply ${ }^{1}$ versus population indices and rate of population change in the Great Spotted Woodpecker.

Spearman rangkorrelation för mängden grankottar $^{l}$ mot populationsindexoch årliga förändringstaktenför större hackspett.

\begin{tabular}{llll}
\hline & $\mathrm{r}_{\mathrm{s}}$ & $\mathrm{N}$ & $\mathrm{P}$ \\
\hline $\begin{array}{l}\text { Winter population index } \\
\text { Vinterindex }\end{array}$ & 0.602 & 15 & $<0.03$ \\
$\begin{array}{l}\text { Breeding population index } \\
\text { Häckningsindex }\end{array}$ & 0.205 & 15 & 0.44 \\
$\begin{array}{l}\text { Rate of population change } \\
\text { between winters }\end{array}$ & 0.610 & 14 & $<0.03$ \\
$\begin{array}{l}\text { Förändring mellan vintrar } \\
\text { Rate of population change } \\
\text { between breeding seasons }\end{array}$ & 0.563 & 14 & $<0.05$ \\
$\begin{array}{l}\text { Förändring mellan häck- } \\
\text { ningssäsonger }\end{array}$ & & & \\
\hline
\end{tabular}

' Spruce seed production recorded in five semi quantitative classes at Stenbrohult, southern Småland in 1975-90 were: 0, $4,0,4,0,4,0,0,5,0, ?, 0,4,0,5,3$.

'Granens kottproduktion registrerades ifem semikvantitativa klasser i Stenbrohult, södra Småland 1975-90:0, 4, 0, 4, 0, 4, $0,0,5,0, ?, 0,4,0,5,3$.

winter and breeding season, except in the Black Woodpecker for which there was no significant difference in the breeding season (Table 1 and 2). The Lesser Spotted Woodpecker was equally common in both regions (Table 2).

\section{Discussion}

\section{Black and Great Spotted Woodpecker-species with no} trend

The Black and Great Spotted Woodpeckers are the most common woodpeckers in Sweden since they can occur in managed forests without deciduous trees (e.g. Nilsson 1979). Since such forests are becoming more common in Sweden (Svensson in press) it is logical that the populations of these two species do not decrease. However, it is perhaps surprising that our data do not indicate increasing populations. It is possible that the area with new coniferous forests is not properly represented in the data set. Another reason could be that the expansion of the coniferous forest area occurs simultaneously with a concomitant decrease in the average quality of the forest for woodpeckers.

Both species prefer old unmanaged forests (Nilsson 1979, Tomiałojc et al. 1984). The species that depend on such forests decline rapidly (see introduction and 
below), and it is therefore not farfetched to assume that whatever factors are constraining them may also, to some extent, influence the Black and Great Spotted Woodpeckers. The Black Woodpecker also needs big trees for hole excavation. Young forests lack such trees and have a low density of Black Woodpeckers (Wahlström 1982). The average clear-cut area is much larger in north than in south Sweden. Hence it is possible that these species may have declined in the north. However, we lack counts there to be able to judge.

\section{Lesser Spotted Woodpecker}

The suggestion that the Lesser Spotted Woodpecker is decreasing in Sweden (SOF 1990) was confirmed by this study. It has decreased by about $50 \%$ over a period of about ten years (Fig. 3), a rate similar to that of the endangered White-backed Woodpecker in both Sweden and Finland (Tiainen 1985, Aulén 1986). Also in Finland, the Lesser Spotted Woodpecker has decreased continuously since monitoring began more than 30 years ago (Tiainen 1985, Väisänen \& Koskimies 1989). It mainly feeds on wood-living insects from autumn to late spring (Glutz von Blotzheim \& Bauer 1980, Cramp 1985), and prefers old unmanaged deciduous forests (Spitznagel 1990, Olsson et al. in press, Pettersson \& Fiskesjö in press). Its territory in an optimal habitat is about 20 ha (Ahlén \& Nilsson 1982, Wesolowski \& Tomiałojć 1986, Spitznagel 1990), but larger in managed forests (Wiktander et al. in press).

Swedish forest statistics is not suitable for an evaluation of the forest qualities in relation to the requirements of woodpeckers mainly dependent on dead deciduous wood. We know that the area of nemoral deciduous forest decreased with about $1 \%$ yearly in 1960-1980 (Naturvårdsverket 1982). Since such forests are important habitats for the Lesser Spotted Woodpecker (Olsson et al. in press, Wiktander et al. in press) the decrease of the species could be due to decreasing amounts of suitable habitat. To evaluate this hypothesis there is a need for more appropriate forest statistics. However the decrease of the woodpecker is much faster than is the decrease of deciduous forest. One reason could be increasingly denser forests. Most wood beetles dependent on deciduous trees are favoured by sunexposure of trees (Nilsson \& Ericson 1991). Thus, it is possible that the food density has decreased in dead branches due to the denser forests. Another reason could be the inherent non-linearity predicted by models of extinction processes (e.g. Lande 1987). When a suitable habitat decreases, the dependent populations are expected to decrease even more.

Another possible explanation of the decline of the Lesser Spotted Woodpecker, also related to changes in forest composition, is competition with the Great Spotted Woodpecker. When the amount of spruce increases in relation to the amount of deciduous trees in the forests, as is the case in southern Sweden, the Great Spotted Woodpecker can increase in spruce mast years (Table 4). When the seed crop of spruce fails the Great Spotted Woodpecker is forced to forage on wood dwelling insects (own observations), perhaps reducing the amount of food for the Lesser Spotted Woodpecker. In such years, the Great Spotted Woodpecker may concentrate its foraging to the successively decreasing proportion of deciduous forests intensifying the assumed competition between the two woodpecker species. If this hypothesis is correct the smaller species could decline even if the deciduous forest area is unchanged when the coniferous area increases. We point out the high population level of the Great Spotted Woodpecker around 1980 (Fig. 2), coinciding with the strongest decline of the Lesser Spotted Woodpecker (Fig. 3). However, we found no significant correlation between the population index of the Great Spotted Woodpecker and the rate of change in the index for the Lesser Spotted Woodpecker.

\section{Green Woodpecker}

The decrease of the Green Woodpecker population has not been recorded by ornithologists in Sweden (SOF 1990), probably because the decline was only 20 - $30 \%$ over a period of about ten years (Fig. 4). This species, as well as the migratory Wryneck, which is also declining (Svensson in press), feeds mainly on ants (Glutz von Blotzheim \& Bauer 1980, Cramp 1985), often on pastures with scattered trees. Such habitats have decreased continuously in area during more than 50 years in Sweden (Anonymous 1984). Further, Svensson (in press) suggested that the decline of the Green Woodpecker was due to the selective removal of deciduous trees in mixed coniferous/deciduous stands. The habitat requirements of the Wryneck and the Green Woodpecker ought to be examined in detail.

\section{Population fluctuations}

Several resident passerines in northern Europe fluctuate according to mean winter temperatures (e.g. Källander \& Karlsson 1981, Svensson 1981, Nilsson 1986, 1987). Among passerine populations, small species are more strongly affected by cold winters than are larger species (Graber \& Graber 1979, Cawthorne \& Marchant 1980). This is partly because the surface/volume ratiodecreases with increasing body size. Thus, we would also expect smaller woodpeckers to be most depressed by cold weather. However, we found the opposite tendency. 
The population sizes of Lesser and Great Spotted Woodpeckers, as well as the Green Woodpecker, seem to be unaffected by cold winters. On the other hand, the Black Woodpecker was recorded in lower numbers in cold winters. It is possible that the correlation we found is because we performed eight analyses and found one significant correlation by chance. Another possibility is that the correlation is valid and that in cold winters the activity and hence detectability is depressed in this species and perhaps also in the Green Woodpecker (Table 3). The lack of correlation between winter weather and the subsequent breeding population index supports this explanation. However, it is also possible that foraging of the Black and the Green Woodpecker is more difficult during cold winters with much snow, since they forage more on the ground than the two smaller species. The higher frequency of the Black and the Green Woodpecker in southernmost Sweden (Table 1) in contrast to frequencies for the Lesser and Great Spotted Woodpeckers is consistent with such an explanation. Censuses in large plots have revealed a higher density of Black Woodpeckers in southern compared to central Sweden (Tjernberg, Johnsson \& Nilsson in prep.).

\section{Acknowledgments}

This study depends entirely on the work of all the volunteers who has been collecting the data through the years. The project was financially supported by the Swedish Environmental Protection Agency and WWF Sweden.

\section{References}

Ahlén,I. \& Nilsson,S.G. 1982. Species richness and area requirements of forest bird species on islands with natural forests in Lake Mälaren and Hjälmaren. Vår Fågelvärld 41:161-184. In Swedish with English summary.

Anonymous. 1984. Naturmiljön i siffror. Miljöstatistisk årsbok 1983-84. Statistiska Centralbyrån, Stockholm.

Aulén,G. 1985. Vitryggiga hackspetten - kommer den att överleva? Vår Fågelvärld 44:95-105.

Aulén,G. 1986. The distribution and status of the Whitebacked Woodpecker Dendrocopos leucotos in Sweden. Vår Fågelvärld 45:201-226. In Swedish with English summary.

Aulén, G., Haavisto, S., Holmstedt, S. \& Turesson, A. 1989. The White-backed Woodpecker in 1988. Vår Fågelvärld 48:227-230. In Swedish with English summary.

Balen, J.H. van. 1980. Population fluctuations of the Great Tit and feeding conditions in winter. Ardea 68:143-164.

Cawthorne, R.A. \& Marchant, J.H. 1980. The effects of the $1978 / 79$ winter on British bird populations. Bird Study $27: 163-172$.
Cramp,S. (ed). 1985. The birds of the Western Palearctic. Vol. IV. Oxford University Press, Oxford.

Glutz von Blotzheim,U.N. \& Bauer,K.M. 1980. Handbuch der Vögel Mitteleuropas. Band 9. Akademische Verlagsgesellschaft, Wiesbaden.

Graber, J.W. \& Graber, R.R. 1979. Severe winter weather and bird populations in southern Illinois. Wilson Bull. 91:88103.

Källander, H. \& Karlsson, J. 1981. Population fluctuations of some north Europaean bird species in relation to winter temperatures. Proceedings of the Second Nordic Congress of Ornithology 1979, pp 111-117.

Källander, H., Nilsson, S.G. \& Svensson, S. 1977. The Swedish winter bird census programme. Polish Ecol Stud. 3:77-88.

Lande, R. 1987. Extinction thresholds in demographic models of territorial populations. Amer Nat. 130:624-635.

Naturvårdsverket. 1982. Ädellövskog, förslag till skydd och vård. SNV PM 1587. Statens Naturvårdsverk, Solna. 175 pp.

Nilsson,S.G. 1979. Density and species richness of some forest bird communities in south Sweden. Oikos 33:392401 .

Nilsson, S.G. 1986. Density-independence and densitydependence in the population dynamics of the Wren Troglodytes Iroglodytes and the Goldcrest Regulus regulus. Vår Fågelvärld, Supplement 11:155-160.

Nilsson, S.G. 1987. Limitation and regulation of population density in the Nuthatch Sitta europaea breeding in natural cavities. J Anim. Ecol. 56:921-937.

Nilsson, S.G. \& Ericson, L. 1991. Conservation of plant and animal populations in theory and practice. Pp.71-112 in The ecological principles of nature conservation (Hansson, $\mathrm{L}$. ed). Elsevier Science Publishers Ltd, U.K.

Olsson,O., Nilsson,I.N., Nilsson,S.G., Pettersson,B., Stagen,A. \& Wiktander,U. in press. Habitat preferences of the Lesser Spotted Woodpecker Dendrocopos minor. Ornis Fennica.

Pettersson,B. 1985. Extinction of an isolated population of the Middle Spotted Woodpecker Dendrocopos medius in Sweden and its relation to general theories on extinction. Biol. Conserv. 32:335-353.

Pettersson,B. \& Fiskesjö,A. in press. Flora and fauna in natural deciduousforests, conservation evaluation, selection and management of stands. Statens Naturvårdsverk, Solna. In Swedish with English summary.

Scherzinger, W. 1990. Is competition by the Great Spotted Woodpecker the cause for White-backed Woodpeckers rarity in Bavarian Forest National Park? Pp 81-91 in Conservation and management of woodpecker populations (Carlson,A. \& Aulén,G. eds). Swedish University of Agricultural Sciences, Department of Wildlife Ecology, Report 17. Uppsala, Sweden.

SOF. 1990. Sveriges fåglar. Stockholm.

Spitznagel,A. 1990. The influence of forest management on woodpecker density and habitat use in floodplain forests of the Upper Rhine Valley. Pp 117-145 in Conservation and management of woodpecker populations (Carlson,A. \& Aulén,G. eds). Swedish University of Agricultural Sciences, Department of Wildlife Ecology, Report 17. Uppsala, Sweden. 
Svensson, S. 1981. Population fluctuations in tits Parus, Nuthatch Sitta europaea and Treecreeper Certhia familiaris in south Sweden. Proceedings of the Second Nordic Congress of Ornithology 1979, pp 9-18. In Swedish with English summary.

Svensson, S. 1991. Bird population monitoring in Sweden. Naturvårdsverket, Rapport 3953. Solna, Sweden.

Svensson, S. in press. Recent population trends of common birds and modern forestry in Sweden. Proceedings of the Seventh Nordic Ornithological Congress 1990.

Tiainen,J. 1985. Monitoring bird populations in Finland. Ornis Fennica 62:80-89.

Tomiałojć, L., Wesołowski, T. \& Walankiewicz, W. 1984. Breeding bird community of primeval temperate forest (Bialowieza National Park, Poland). Acta Ornithologica 20:241-310.

Väisänen,R.A. \& Koskimies,P. 1989. Winter birds in Finland in 1988/89, their long-term trends and densities in different habitats. Lintumies 24:190-203. In Finnish with English summary.

Wahlström, K. 1982. Spillkråkans populationstäthet och val av boträd i en sydsvensk skog. Milvus 12:88-97.

Wesolowski,T. \& Tomiałojć,L. 1986. The breeding ecology of woodpeckers in a temperate primeval forest - preliminary data. Acta Ornithologica 22:1-21.

Wiktander, U., Nilsson, I.N., Nilsson, S.G., Olsson, O., Pettersson, B. \& Stagen, A. in press. Occurrence of the Lesser Spotted Woodpecker Dendrocopos minor in relation to area of deciduous forest. Ornis Fennica.

\section{Sammanfattning}

\section{Beståndstrender och fluktuationer hos svenska hack- spettar}

Hackspettarna omfattar flera hotade arter. Den i vårt land ekberoende mellanspetten har försvunnit helt. Vitryggiga hackspetten, som behöver stora arealer med gamla lövträd, har minskat kraftigt. Nyligen har nedgång befarats för den mindre och den tretåiga hackspetten (SOF 1990). Genom sin generella preferens för äldre naturskog betraktas hackspettarna som goda indikatorer på hur hårt skogen har exploaterats.

Sextonårs data, huvudsakligen från punkttaxeringar från Svenska vinterfågelräkningen 1975/76-1990/91 och Svenska häckfågeltaxeringen 1975-1990, behandlas för spillkråka, gröngöling, större hackspett och mindre hackspett. Andelen av punkttaxeringsrutterna med observation av respektive art (observationsfrekvens) analyseras med variansanalys. Materialet regionindelas i en sydlig och en nordlig del med gränsen dragen mellan ruta 9 och 10 i rikets nät, ungefär motsvarande en linje dragen genom Strömstad, Hallsberg och Katrineholm. Denna delning ger två likstora delar av materialet. Rutterna från den norra regionen härrör huvudsakligen från Svealand

Resultaten (Tabell 1 och 2) visar att populationstrenderna är lika för olika regioner och perioder inom en art. Ett undantag är gröngölingen där data från häckningstiden visar på en kraftigare nedgång $(-2.1 \%$ per år) än under vintern (-1.7\% per år). Data från hösten visar på samma nedgångstakt som under häckningstiden medan det för december-mars endast finns en svag icke signifikant nedgång.

Trots att vi har jämförelsevis få observationer av mindre hackspett visarden en genomgående och mycket stark tillbakagång (-4\% per år). Minskningstakten är lika hög som för vitryggig hackspett $i$ både Sverige och Finland. För större hackspett och spillkråka finner vi inga populationstrender (jfr Svensson i tryck).

Större hackspetten och spillkråkan är de två arter som påverkas minst av dagens skogsbruk eftersom de kan leva även i intensivt skötta skogar, förutsatt att det finns lämpliga boträd. Följdriktigt visar de inga beståndstrender under 1975-1991, en period under vilken vintertemperaturen inte heller hade någon trend.

Hackspettar som tycks föredra naturbetesmarker för sitt födosök minskar, liksom denna naturtyp. Gröngölingens minskning har inte tidigare uppmärksammats av ornitologer, kanske beroende på att minskningen endast är 20-30\% på tio år. Göktytans snabba minskning (Svensson i tryck) har dock uppmärksammats (SOF 1990). Dessa två arters biotopkrav borde analyseras närmare.

Mindre hackspettens snabba minskningstakt är inte så lätt att förklara som det kanske anses bland ornitologer. Arten har minskat mycket snabbare än mängden lövträd. Vi föreslår tre tänkbara förklaringar:

1. Ädellövskog är en föredragen biotop (Olsson m.fl. i tryck, Wiktander m.fl. i tryck) som har minskat med ca 1\% per år 1960-1980. Kanske är ädellövskogarna nyckelbiotoper i landskapet för mindre hackspetten. Bland skötta lövskogar är det endast ädellövskogarna som tillåts bli gamla (se t.ex. Olsson m.fl. i tryck). Att mindre hackspetten minskar betydligt snabbare än lövskogen kan bero på det generella faktum att när lämplig biotop minskar går de därav beroende arterna tillbaka snabbare än biotopytan (se t.ex. Lande 1987). Statistiken från riksskogstaxeringen är dock inte tillräckligt detaljerad för att beräkna minskningstakten för speciella skogstyper.

2. Skogarna har blivit tätare vilket missgynnar många vedlevande lövträdsskalbaggar (Nilsson \& Ericson 1991). Kanske har födomängden per döende och död lövträdsgren minskat p.g.a. att beskuggningen på grenarna ökat.

3. Större hackspetten ökar vid riklig tillgång på kottar (se nedan). Vintrar då det saknas kottar lever arten främst på vedlevande skalbaggar i likhet med mindre hackspetten (egna observationer). Om skogen ändras så att andelen barrträd ökar, vilket sker i dagens svenska skogar, gynnas större hackspetten under år med riklig tillgång på kottar. Detta innebär att mängden 
större hackspettar som söker föda i den mindre artens huvudbiotop, lövskogar, ökar vid utebliven kottsättning. Vi tror att detta kan påverka den mindre hackspetten negativt genom lägre överlevnad. Åren kring 1980 sammanfaller en hög täthet av större hackspetten med en särskilt snabb minskning av mindre hackspetten (Fig. 2 och 3).

Beståndsindex för de fyra hackspettarterna jämfördes med medeltemperaturen för december-februari (medel för Växjö och Örebro). Endast vinterindex för spillkråka var signifikant korrelerat med temperaturen (Tabell 3). Det är möjligt att spillkråkan, och eventuellt gröngölingen, påverkas negativt av kalla vintrar, men ocksà aut aktiviteten och därmed observerbarheten minskar vid kallt väder. Beståndsindex för större hackspett och förändringshastigheten för beståndsindex visar positiva samband med mängden grankottar (grankottedata från södra Småland). Det är känt att grankotteproduktionen samvarierar över större områden.

Observationsfrekvenserna varierar regionalt för tre arter. Gröngöling och spillkråka vintertid visar högre frekvens i den sydliga regionen än i den norra. Större hackspetten visar det omvända mönstret. Mindre hackspetten visar samma frekvens i båda regionerna. Det nordliga materialet domineras dock helt av Svealand, tyvärr finns få rutter från Norrland. 